19 Revue d'histoire du XIXe siècle

Société d'histoire de la révolution de 1848 et des

révolutions du XIXe siècle

19 | 1999

Aspects de la production culturelle au XIXe siècle

\title{
Justice et recherches : bilan des travaux et nouveaux chantiers
}

\section{OpenEdition}

\section{Journals}

Édition électronique

URL : http://journals.openedition.org/rh19/188

DOI : 10.4000/rh19.188

ISSN : $1777-5329$

Éditeur

La Société de 1848

Édition imprimée

Date de publication : 1 décembre 1999

Pagination : 172

ISSN : 1265-1354

\section{Référence électronique}

" Justice et recherches : bilan des travaux et nouveaux chantiers », Revue d'histoire du XIXe siècle [En

ligne], 19 | 1999, mis en ligne le 26 août 2008, consulté le 15 septembre 2020. URL : http:// journals.openedition.org/rh19/188

Ce document a été généré automatiquement le 15 septembre 2020.

Tous droits réservés 


\section{Justice et recherches : bilan des travaux et nouveaux chantiers}

1 Organisée à l'Université de Poitiers, le 14 mars 2000, cette manifestation regroupera nombre de chercheurs venant d'horizons divers. Elle entendra faire le point sur les travaux les plus marquants relatifs à la justice et insistera, de manière prospective, sur les priorités de la recherche et les chantiers ouverts récemment.

Renseignements : Frédéric Chauvaud, Université de Poitiers, UFR sciences humaines et arts, Département d'histoire, 8 rue Descartes, 86022 Poitiers cedex, Tél. : 0549454540 ou 0549454756 (secrétariat), Fax : 0549454817. 